\title{
Isolation and Characterization of Methanolobus bombayensis sp. nov., a Methylotrophic Methanogen That Requires High Concentrations of Divalent Cations
}

\author{
PRIYA C. KADAM, ${ }^{1,2}$ D. R. RANADE, ${ }^{2}$ LINDA MANDELCO, ${ }^{3}$ AND DAVID R. BOONE ${ }^{1,4 *}$ \\ Department of Chemistry, Biochemistry, and Molecular Biology ${ }^{1}$ and Department of Environmental Science and \\ Engineering, ${ }^{4}$ Oregon Graduate Institute of Science \& Technology, Portland, Oregon 97291-1000; \\ Department of Microbiology, Agharkar Research Institute, Pune 411004, India ${ }^{2}$; and \\ Department of Microbiology, University of Illinois, Urbana, Illinois $61801^{3}$
}

\begin{abstract}
Methanolobus bombayensis B-1 ${ }^{\mathrm{T}}\left(=\mathrm{OCM} 438^{\mathrm{T}}\right)(\mathrm{T}=$ type strain) was isolated from Arabian Sea sediments obtained near Bombay, India. This strain grew on methylamines, methanol, and dimethyl sulfide, but it did not catabolize $\mathrm{H}_{2}-\mathrm{CO}_{2}$, acetate, or formate. The cells were nonmotile, irregular coccoids (diameter, 1.0 to $1.5 \mu \mathrm{m}$ ) and occurred singly. Electron micrographs revealed that a cell membrane and a protein cell wall were present. The cells grew fastest at mesophilic temperatures, at a neutral $\mathrm{pH}$, and at salinity levels near the salinity level of the ocean, and they required about $30 \mathrm{mM}$ divalent cations $\left(\mathrm{Mg}^{2+}\right.$ and $\left.\mathrm{Ca}^{2+}\right)$. The cells grew in mineral medium, but growth was greatly stimulated by yeast extract and peptones. The guanine-plus-cytosine content of the DNA was $39.2 \pm 0.1$ mol\%. A comparison of $16 \mathrm{~S}$ rRNA sequences showed that strain $\mathrm{B}-1^{\mathrm{T}}$ was phylogenetically related to Methanolobus vulcani, but the sequences of these organisms differed by $2 \%$.
\end{abstract}

Some marine methanogens use either $\mathrm{H}_{2}-\mathrm{CO}_{2}(6-8,11,14$, $34)$ or acetate (30), but many marine isolates and nearly all isolates obtained from hypersaline sources are obligately methylotrophic $(3,17,19,26,35,36)$. Obligately methylotrophic methanogens grow exclusively on methyl compounds (such as methyl amines and methanol). Some of these obligately methylotrophic organisms can also catabolize dimethyl sulfide and methanethiol (7, 10, 22, 25). Methanosphaera species, which grow by using $\mathrm{H}_{2}$ to reduce methanol to methane, are not considered obligate methylotrophs, nor are Methanosarcina species that catabolize acetate or $\mathrm{H}_{2}-\mathrm{CO}_{2}$ as well as methylotrophic substrates.

The family Methanosarcinaceae contains all known halophilic, methylotrophic methanogens. These organisms include extreme halophiles (in the genus Methanohalobium), moderate halophiles (in the genus Methanohalophilus), and slight halophiles (in the genera Methanolobus and Methanococcoides and one Methanosarcina species, Methanosarcina siciliae). Methanosarcina siciliae is a synonym of Methanolobus siciliae (24).

In this paper we describe the isolation of a slightly halophilic, methylotrophic methanogen that requires high concentrations of $\mathrm{Mg}^{2+}$, Methanolobus bombayensis sp. nov. strain $\mathrm{B}-1^{\mathrm{T}}(\mathrm{T}=$ type strain $)$.

\section{MATERIALS AND METHODS}

Source of inoculum. Strain $B-1^{T}$ was isolated from an Arabian Sea sediment sample obtained near Bombay, India. The sample was transported to a laboratory under anoxic conditions within $24 \mathrm{~h}$.

Media and culture techniques. Modifications (21) of the anaerobic techniques of Hungate (12) were used. The composition of SWM medium was (per liter) $1.0 \mathrm{~g}$ of $\mathrm{Na}_{2} \mathrm{SO}_{4}, 30 \mathrm{~g}$ of $\mathrm{NaCl}, 0.7 \mathrm{~g}$ of $\mathrm{KCl}, 10 \mathrm{~g}$ of $\mathrm{MgCl}_{2} \cdot 6 \mathrm{H}_{2} \mathrm{O}, 1.0 \mathrm{~g}$ of $\mathrm{CaCl}_{2}, 0.2$ $\mathrm{g}$ of $\mathrm{NaHCO}_{3}, 0.1 \mathrm{~g}$ of $\mathrm{K}_{2} \mathrm{HPO}_{4}, 0.25 \mathrm{~g}$ of $\mathrm{NH}_{4} \mathrm{Cl}, 2 \mathrm{mg}$ of

* Corresponding author. Mailing address: Department of Environmental Science and Engineering, Oregon Graduate Institute, P.O. Box 91000, Portland, OR 97291-1000. Phone: (503) 690-1146. Fax: (503) 690-1273. Electronic mail address: boone@ese.ogi.edu.
$\mathrm{Fe}\left(\mathrm{NH}_{4}\right)_{2}\left(\mathrm{SO}_{4}\right)_{2}, 2 \mathrm{~g}$ of yeast extract, $2 \mathrm{~g}$ of peptones, $1.0 \mathrm{mg}$ of resazurin, and $10 \mathrm{ml}$ of a trace element solution (33). All of the constituents except sulfide were dissolved in water, boiled, and cooled under an $\mathrm{O}_{2}$-free mixture of $\mathrm{N}_{2}$ and $\mathrm{CO}_{2}(4: 1)$. The medium was distributed to serum bottles under the same gas mixture, and then the bottles were sealed and autoclaved at $121^{\circ} \mathrm{C}$ for $20 \mathrm{~min}$. Sulfide from a sterile anoxic stock solution was added before inoculation. The $\mathrm{pH}$ of the medium was 7.2. For solid medium, $18 \mathrm{~g}$ of purified agar per liter was added. For other experiments we used a modification of MSH medium (22), a bicarbonate-buffered medium containing yeast extract, peptones, and $29.2 \mathrm{~g}$ of $\mathrm{NaCl}$ per liter. This medium was modified by increasing the concentration of $\mathrm{MgCl}_{2} \cdot 6 \mathrm{H}_{2} \mathrm{O}$ from $2.7 \mathrm{~g}$ to $6.1 \mathrm{~g} /$ liter. Methanol $(20 \mathrm{mM})$ was added as a catabolic substrate. To measure the effect of $\mathrm{pH}$ on growth, the $\mathrm{pH}$ of the medium was modified by adjusting the ratio of $\mathrm{N}_{2}$ to $\mathrm{CO}_{2}$ in the gas. Adjusting the fraction of $\mathrm{CO}_{2}$ resulted in media with $\mathrm{pH}$ values between $6.8\left(100 \% \mathrm{CO}_{2}\right)$ and $8.0\left(100 \% \mathrm{~N}_{2}\right)$. Media with $\mathrm{pH}$ values lower than 6.8 were obtained from $100 \%$ $\mathrm{CO}_{2}$ medium by adjusting the $\mathrm{pH}$ with $\mathrm{HCl}$. Media with $\mathrm{pH}$ values higher than 8.0 were obtained from $100 \% \mathrm{~N}_{2}$ medium by adding $\mathrm{NaOH}$. The decreases in $\mathrm{pH}$ during growth (due to $\mathrm{CO}_{2}$ production) were small; the greatest decreases in $\mathrm{pH}$ $(0.25 \mathrm{pH}$ unit) occurred during growth in medium that had an initial $\mathrm{pH}$ of 8.0 .

Determination of catabolic substrates. The use of catabolic substrates was determined by inoculating cultures into media containing various catabolic substrates (soluble substrates at concentrations of $20 \mathrm{mM}$ or gaseous substrates at partial pressures of $0.7 \mathrm{~atm}$ [ca. $71 \mathrm{kPa}$ ]) and monitoring methanogenesis. Methane formation was compared with the methane formation in controls lacking a catabolic substrate, and cultures producing significant amounts of methane were transferred to fresh medium. The methanogenic rates of these cultures were evaluated to determine whether methanogenesis was accompanied by growth. Those cultures that did not produce significantly more methane than the controls lacking substrate were checked for methanogenesis after at least 4 weeks of incubation.

Determination of growth rates. Specific growth rates were 
calculated from the amounts of methane produced during growth (5). The specific growth rate during exponential growth was analyzed by linear regression of the logarithm of the total amount of methane that accumulated (including the methane produced by the inoculum [27]) and time. Inocula were grown under conditions similar to the experimental conditions.

Analytical techniques. The amount of methane was determined by gas chromatography with flame ionization detection (17). DNA was isolated by the method of Marmur (18), and the DNA guanine-plus-cytosine content was determined by high-performance liquid chromatography after enzymatic hydrolysis (20). We examined cells microscopically with an epifluorescence microscope equipped with a type $\mathrm{O} 2$ filter set (Carl Zeiss, Inc., Thornwood, N.Y.).

The reverse transcriptase method was used to sequence the $16 \mathrm{~S}$ rRNA. The samples used for electron microscopy were fixed in a cacodylate-buffered solution containing osmium tetroxide (10 g/liter) and glutaraldehyde (25 g/liter) (1);30 mM $\mathrm{Mg}^{2+}$ was included in all of the buffers.

\section{RESULTS AND DISCUSSION}

Isolation. We inoculated sediment samples into four bottles containing SWM medium ( $2 \mathrm{ml}$ of inoculum was inoculated into $18 \mathrm{ml}$ of medium). Two bottles contained $50 \mathrm{mM}$ acetate as the catabolic substrate, and two bottles contained $50 \mathrm{mM}$ methanol. After 30 days of incubation at $35^{\circ} \mathrm{C}$, the methanol cultures but not the acetate cultures had produced methane. One methanol enrichment culture was grown in medium containing vancomycin hydrochloride $(0.1 \mathrm{~g} /$ liter $)$ to decrease the proportion of nonmethanogenic contaminants, and this culture was inoculated into roll tube medium for further purification. We picked a well-isolated colony that appeared after 2 weeks of incubation and aseptically transferred it to liquid medium under a stream of $\mathrm{O}_{2}$-free $\mathrm{N}_{2}$. The resulting culture was diluted and reinoculated into roll tube medium. This procedure was repeated until a single type of colony was obtained. The resulting culture was determined to be axenic on the basis of a microscopic examination of wet mounts, the presence of a single colony type in roll tube medium, and the absence of growth in either SWM medium lacking substrate or nutrient broth supplemented with $10 \mathrm{~g}$ of glucose per liter. We designated this culture strain $\mathrm{B}-1^{\mathrm{T}}$ and deposited it in the Oregon Collection of Methanogens as strain OCM $438^{\mathrm{T}}$.

Colonial and cell morphology. Surface colonies were circular, convex with entire margins, colorless, translucent, and 2 to $3 \mathrm{~mm}$ in diameter after incubation for 7 to 10 days. The cells were very irregular coccoids with diameters of 1.0 to $1.5 \mu \mathrm{m}$. The cells were nonmotile, and thin-section electron micrographs revealed no flagella. The Gram stain reaction was negative.

The cells lysed immediately when $0.1 \mathrm{~g}$ of sodium dodecyl sulfate per liter was added, indicating that a proteinaceous cell wall was present (6). Electron microscopy also revealed an S-layer (Fig. 1). When cells were suspended in a buffer having the same osmolality as their medium but containing no $\mathrm{MgCl}_{2}$ or $\mathrm{CaCl}_{2}$, they became turgid and spherical. In Methanococcus voltaei, $\mathrm{Ca}^{2+}$ and $\mathrm{Mg}^{2+}$ stabilize the cell envelope and are tightly bound to the wall protein (13); whether they serve the same function in strain $\mathrm{B}-1^{\mathrm{T}}$ is unknown.

Methylotrophy and environmental factors for growth. Physiological studies conducted with modified MSH medium and with SWM medium gave similar results. Strain $\mathrm{B}-1^{\mathrm{T}}$ catabolized methanol, trimethylamine, and dimethyl sulfide. Cultures containing $\mathrm{H}_{2}$ and $20 \mathrm{mM}$ methanol produced the same amount of methane as cultures containing only $20 \mathrm{mM}$ meth-

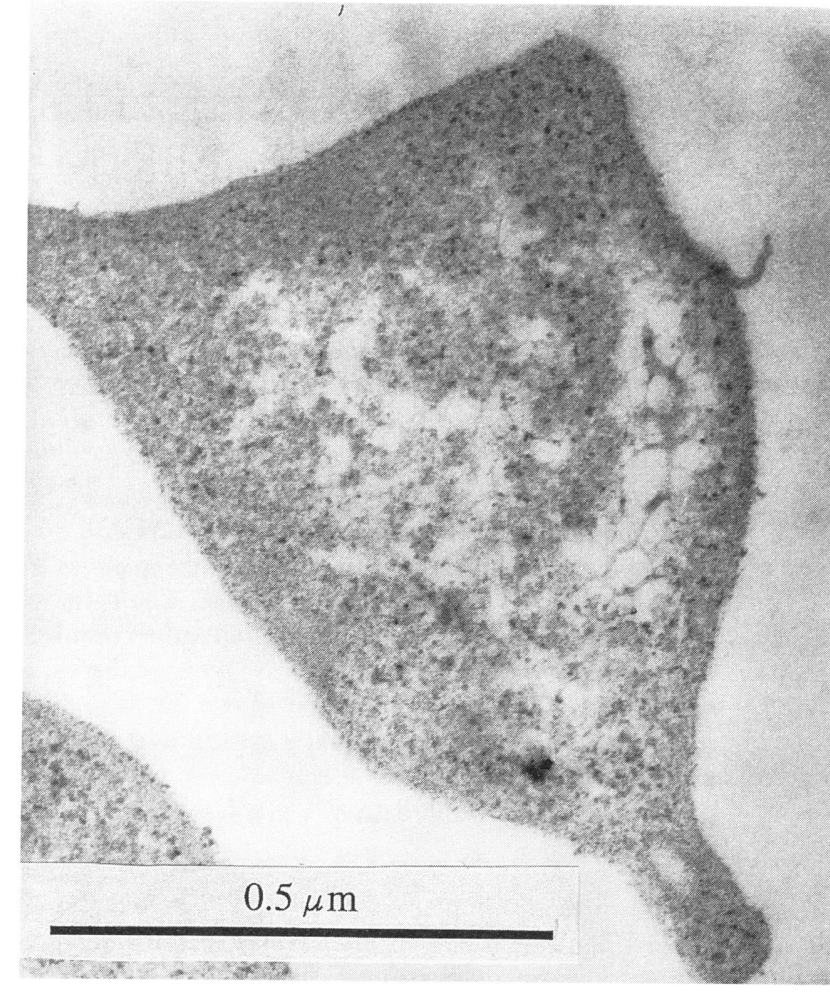

FIG. 1. Thin-section electron micrograph showing a coccoid cell grown in liquid medium containing $30 \mathrm{mM} \mathrm{Mg}^{2+}$.

anol. Cultures did not use formate, acetate, or $\mathrm{H}_{2}-\mathrm{CO}_{2}$. Cells grew fastest at neutral pH values (Fig. 2) and in the presence of about $0.5 \mathrm{M} \mathrm{NaCl}$ (Fig. 3). The levels of salinity tolerated by strain $\mathrm{B}-1^{\mathrm{T}}$, which grew in the presence of $2 \mathrm{M} \mathrm{NaCl}$ (Fig. 3), were higher than the levels of salinity tolerated by other Methanolobus strains (6). Strain B-1 $1^{\mathrm{T}}$ was mesophilic (Fig. 4). Using the square root model $(15,28)$, we analyzed the effect of temperature on the specific growth rate and found that strain B-1 $1^{\mathrm{T}}$ cells could not grow at $13.2^{\circ} \mathrm{C}$ or at temperatures below $13.2^{\circ} \mathrm{C}$ or at $45.7^{\circ} \mathrm{C}$ or at temperatures above $45.7^{\circ} \mathrm{C}$ and that

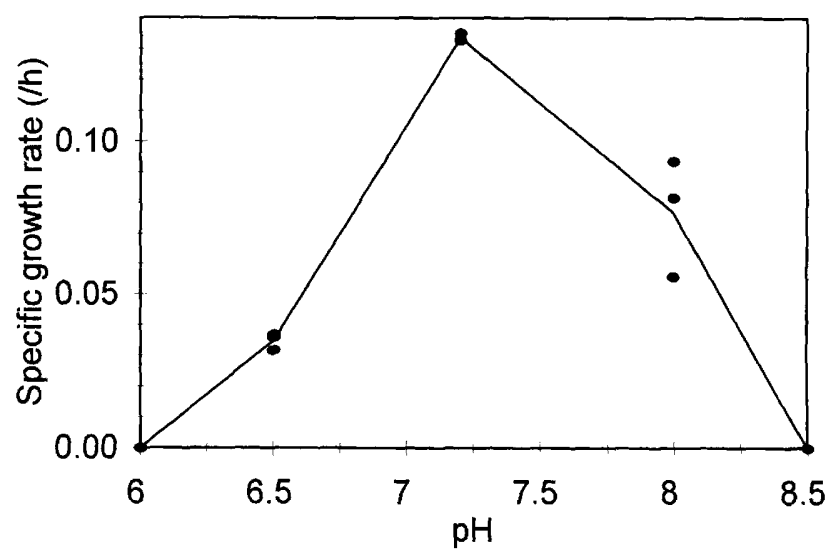

FIG. 2. Effect of initial $\mathrm{pH}$ on the specific growth rate of strain $\mathrm{B}-1^{\mathrm{T}}$. The results of three replicate measurements at each of five $\mathrm{pH}$ values are shown (some of the symbols overlap). The solid line connects the average growth rates at the $\mathrm{pH}$ values tested. 


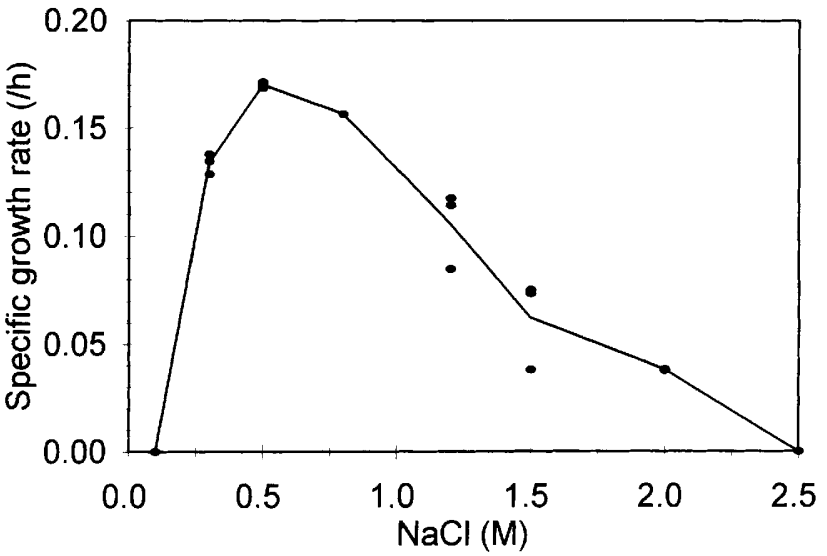

FIG. 3. Effect of $\mathrm{NaCl}$ on the specific growth rate of strain $\mathrm{B}-1^{\mathrm{T}}$. The results of three replicate measurements at each of eight levels of salinity are shown (some of the symbols overlap). The solid line connects the average growth rates at the levels of salinity tested.

they could grow fastest at $36.6^{\circ} \mathrm{C}$ (Fig. 4). However, we did not detect growth at $45^{\circ} \mathrm{C}$.

Requirement for a high concentration of $\mathrm{Mg}^{2+}$. Strain $\mathrm{B}-1^{\mathrm{T}}$ did not grow in MSH medium, which contained $13 \mathrm{mM} \mathrm{Mg}^{2+}$ and $3 \mathrm{mM} \mathrm{Ca}^{2+}$, unless the concentration of $\mathrm{Mg}^{2+}$ or $\mathrm{Ca}^{2+}$ was increased. When the $\mathrm{Ca}^{2+}$ concentration in the medium was $3 \mathrm{mM}$, cells grew well in the presence of 30 to $85 \mathrm{mM}$ $\mathrm{Mg}^{2+}$, but they grew poorly or not at all in the presence of 20 $\mathrm{mM} \mathrm{Mg}{ }^{2+}$. Cells also grew in MSH medium when the concentration of $\mathrm{Mg}^{2+}$ was $13 \mathrm{mM}$ if the $\mathrm{Ca}^{2+}$ concentration was increased to $20 \mathrm{mM}$. Although species belonging to the genera Methanococcoides and Methanolobus generally grow fastest in medium containing 40 to $60 \mathrm{mM} \mathrm{Mg}^{2+}(16,17,22,31)$, they differed from strain $\mathrm{B}-1^{\mathrm{T}}$ because they were able to grow in MSH medium containing $13 \mathrm{mM} \mathrm{Mg}^{2+}$ and $3 \mathrm{mM} \mathrm{Ca}^{2+}$ (data not shown).

Divalent cations play a significant role in biological systems and are known to maintain the ultrastructure of prokaryotes. Elevated $\mathrm{Mg}^{2+}$ and $\mathrm{Ca}^{2+}$ concentrations cause the disaggregation of Methanosarcina species and Methanolobus taylorii

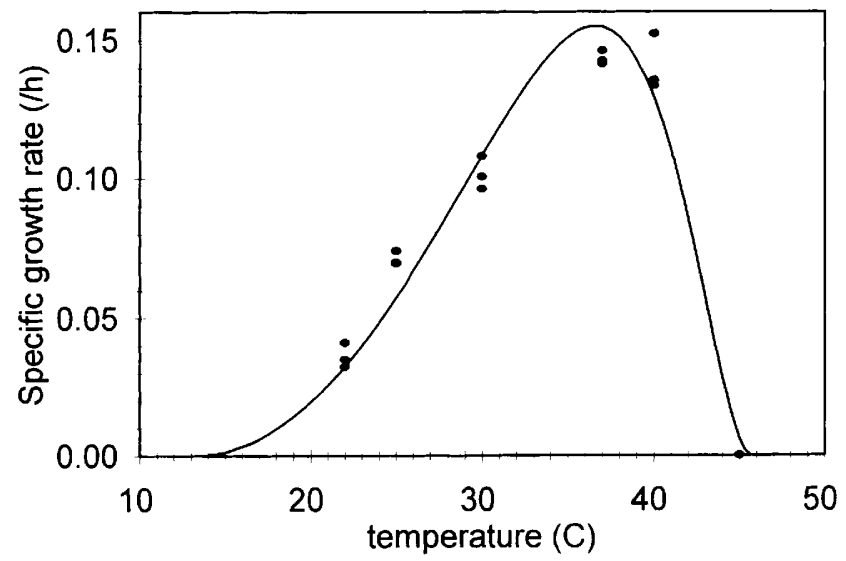

FIG. 4. Effect of temperature on the specific growth rate of strain $\mathrm{B}-1^{\mathrm{T}}$. The results of three replicate measurements at each of six temperatures are shown (some of the symbols overlap). The solid line is the best fit (15) as determined by the square root model (28).
GS-16 ${ }^{\mathrm{T}}$ (= Methanolobus sp. strain GS-16 [4]) (2, 25). Also, these cations may increase the ability of sludge to settle during anaerobic waste treatment; the numbers of packets of coccoidal cells similar to Methanosarcina thermophila cells increase in the presence of $\mathrm{Mg}^{2+}$ in thermophilic upflow anaerobic sludge blanket reactors (29). Methanospirillum strains respond to medium supplemented with low concentration of $\mathrm{Ca}^{2+}$ by growing as long nonflagellated filaments (9).

Requirement for growth factors. Strain $\mathrm{B}-1^{\mathrm{T}}$ grew in mineral medium (specific growth rate, $0.050 \mathrm{~h}^{-1}$ ) when methanol was added as the catabolic substrate. However, it grew faster when other organic compounds were added; the compounds tested included $3 \mathrm{mM}$ 2-mercaptoethanesulfonate (specific growth rate, $0.094 \mathrm{~h}^{-1}$ ), $4 \mathrm{mM}$ sodium acetate (specific growth rate, $0.106 \mathrm{~h}^{-1}$ ), $5 \mathrm{mM}$ glycine betaine (specific growth rate, 0.108 $\mathrm{h}^{-1}$ ), a vitamin mixture (33) (specific growth rate, $0.107 \mathrm{~h}^{-1}$ ), and $2 \mathrm{~g}$ of peptone per liter (specific growth rate, $0.129 \mathrm{~h}^{-1}$ ). Fastest growth occurred when we added $2 \mathrm{~g}$ of yeast extract per liter and $2 \mathrm{~g}$ of peptones per liter (specific growth rate, 0.156 $\mathrm{h}^{-1}$ ).

DNA analysis. The guanine-plus-cytosine content of the DNA was $39.2 \pm 0.1 \mathrm{~mol} \%$. The $16 \mathrm{~S}$ rRNA sequence of strain $\mathrm{B}-1^{\mathrm{T}}$ was compared with the sequences of other methanogens and was found to be most similar to the sequences of Methanolobus strains, especially to the sequence of Methanolobus vulcani, from which it differed by $2 \%$.

Taxonomy. The physiological and morphological characteristics and the results of $16 \mathrm{~S}$ rRNA comparisons indicated that strain B- $1^{\mathrm{T}}$ belongs in the genus Methanolobus. In a previous classification, this genus contained three species, Methanolobus tindarius, Methanolobus vulcani, and Methanolobus siciliae (32). However, on the basis of the results of a 16S rRNA sequence comparison and phenotypic characterization tests, Methanolobus siciliae was transferred to the genus Methanosarcina as Methanosarcina siciliae (24). The results of previous studies also indicated that strain GS-16 (25) belongs in the genus Methanolobus, and the name Methanolobus taylorii has been proposed (4). Methanohalophilus oregonensis also belongs in the genus Methanolobus, and transfer of this species to the genus Methanolobus as Methanolobus oregonensis has been suggested but not formally proposed (6).

Comparisons of the strain B-1 ${ }^{\mathrm{T}} 16 \mathrm{~S}$ rRNA sequence with the sequences of these and other methanogens indicated that strain $\mathrm{B}-1^{\mathrm{T}}$ was most similar to Methanolobus vulcani PL-12/ $\mathrm{M}^{\mathrm{T}}$, but that the sequences of these two organisms were $2 \%$ different. A difference of $2 \%$ in $16 \mathrm{~S}$ rRNA sequences suggests that strains belong in separate species (6). Strain B-1 ${ }^{\mathrm{T}}$ differed from Methanolobus vulcani in some phenotypic characteristics. Unlike Methanolobus vulcani (23), strain $\mathrm{B}-1^{\mathrm{T}}$ required a high concentration of divalent ions. Strain B-1 $1^{\mathrm{T}}$ was also slightly more alkaliphilic than Methanolobus vulcani $\mathrm{PL}-12 / \mathrm{M}^{\mathrm{T}}$; strain B-1 ${ }^{\mathrm{T}}$ grew well at $\mathrm{pH} 8$ but did not grow at $\mathrm{pH} 6$ (Fig. 2), whereas Methanolobus vulcani PL-12/M ${ }^{\mathrm{T}}$ grew well at $\mathrm{pH} 6$ but did not grow at $\mathrm{pH} 8$ (unpublished data).

Strain B- $1^{\mathrm{T}}$ also differed phenotypically from other species that belong to the genus Methanolobus. Strain $\mathrm{B}-1^{\mathrm{T}}$ differed from Methanohalophilus oregonensis WAL1" (= "Methanolobus oregonensis") and Methanolobus taylorii GS-16 ${ }^{\mathrm{T}}$ in that it could not grow at $\mathrm{pH}$ values above 8 . Strain $\mathrm{B}-1^{\mathrm{T}}$ grew in mineral medium containing its catabolic substrate as the only organic addition (as does Methanolobus tindarius [16]), whereas Methanohalophilus oregonensis requires vitamins for growth (17). These phylogenetic and phenotypic distinctions indicate that strain B-1 ${ }^{\mathrm{T}}$ represents a new Methanolobus species. Thus, we propose a new species, Methanolobus bombayensis, with the description given below. 
Methanolobus bombayensis sp. nov. Methanolobus bombayensis (bom.bay.en'sis. N. L. adj. bombayensis, from Bombay, indicating the source of the type strain). Cells are irregular, nonmotile coccoids (diameter, 1 to $1.5 \mu \mathrm{m}$ ) and occur singly. Gram negative. Lysed by $0.1 \mathrm{~g}$ of sodium dodecyl sulfate per liter. Surface colonies are circular, convex, translucent, and colorless with entire margins and have diameters of 2 to $3 \mathrm{~mm}$ after 7 to 10 days of incubation.

The catabolic substrates used include methanol, trimethylamine, and dimethyl sulfide, but not formate, acetate, or $\mathrm{H}_{2}-\mathrm{CO}_{2}$. Grows in mineral medium containing a catabolic substrate; yeast extract and peptones are highly stimulatory.

Sodium and magnesium are required for growth. Fastest growth occurs in the presence of $0.5 \mathrm{M} \mathrm{Na}^{+}$and $\geq 0.03 \mathrm{M}$ $\mathrm{Mg}^{2+}$ at $\mathrm{pH} 7.2$ and $37^{\circ} \mathrm{C}$.

The guanine-plus-cytosine content of the DNA is $39.2 \pm 0.1$ mol\% (as determined by chromatographic analysis of bases).

The habitat is marine sediments. The type strain is strain B-1 (= OCM 438), which was isolated from Arabian Sea sediments obtained near Bombay, India.

\section{ACKNOWLEDGMENTS}

We thank Henry Aldrich, University of Florida, for preparing the electron micrograph and William B. Whitman for determining the guanine-plus-cytosine content of the DNA. We also thank Yitai Liu and Shuisong $\mathrm{Ni}$ for helpful discussions.

This work was supported by Section 105 grant 14-08-001-G1636 from the U.S. Geological Survey.

\section{REFERENCES}

1. Aldrich, H. C., D. B. Beimborn, and P. Schönheit. 1987. Creation of artifactual internal membranes during fixation of Methanobacterium thermoautotrophicum. Can. J. Microbiol. 33:844-849.

2. Boone, D. R., and R. A. Mah. 1987. Effects of calcium, magnesium, $\mathrm{pH}$, and extent of growth on the morphology of Methanosarcina mazei S-6. Appl. Environ. Microbiol. 53:1699-1700.

3. Boone, D. R., I. M. Mathrani, Y. Liu, J. A. G. F. Menia, R. A. Mah, and J. E. Boone. 1993. Isolation and characterization of Methanohalophilus portucalensis sp. nov. and DNA reassociation study of the genus Methanohalophilus. Int. J. Syst. Bacteriol. 43:430437.

4. Boone, D. R., and R. S. Oremland. 1994. Methanolobus taylorii, a new species of methylotrophic, estuarine methanogen. Int. J. Syst. Bacteriol. 44:573-575.

5. Boone, D. R., and W. B. Whitman. 1988. Proposal of minimal standards for describing new taxa of methanogenic bacteria. Int. J. Syst. Bacteriol. 38:212-219.

6. Boone, D. R., W. B. Whitman, and P. Rouvière. 1993. Diversity and taxonomy of methanogens, p. 35-80. In J. G. Ferry (ed.), Methanogenesis. Chapman \& Hall, New York.

7. Burggraf, S., H. Fricke, A. Neuner, J. Kristjansson, P. Rouvière, L. Mandelco, C. R. Woese, and K. O. Stetter. 1990. Methanococcus igneus sp. nov., a novel hyperthermophilic methanogen from a shallow submarine hydrothermal system. Syst. Appl. Microbiol. 13:263-269.

8. Corder, R. E., L. A. Hook, J. M. Larkin, and J. I. Frea. 1983. Isolation and characterization of two new methane-producing cocci: Methanogenium olentangyi, sp. nov., and Methanococcus deltae, sp. nov. Arch. Microbiol. 134:28-32.

9. Faguy, D. M., S. F. Koval, and K. F. Jarrell. 1993. Effect of changes in mineral composition and growth temperature on filament length and flagellation in the archaeon Methanospirillum hungatei. Arch. Microbiol. 159:512-520.

10. Finster, K., Y. Tanimoto, and F. Bak. 1992. Fermentation of methanethiol and dimethylsulfide by a newly isolated methanogenic bacterium. Arch. Microbiol. 157:425-430.

11. Franklin, M. J., W. J. Wiebe, and W. B. Whitman. 1988. Populations of methanogenic bacteria in a Georgia salt marsh. Appl. Environ. Microbiol. 54:1151-1157.
12. Hungate, R. E. 1969. A roll tube method for cultivation of strict anaerobes. Methods Microbiol. 3B:117-132.

13. Jarrell, K. F., and S. F. Koval. 1989. Ultrastructure and biochemistry of Methanococcus voltae. Crit. Rev. Microbiol. 17:53-86.

14. Jones, W. J., D. P. Nagle, Jr., and W. B. Whitman. 1987. Methanogens and the diversity of archaebacteria. Microbiol. Rev. 51:135-177.

15. Kohler, H.-P. E., A. Heitzer, and G. Hamer. 1991. Improved unstructured model describing temperature dependence of bacterial maximum specific growth rates, p. 511-514. In $\mathrm{H}$. Verachtert and W. Verstraete (ed.), International Symposium on Environmental Biotechnology. Royal Flemish Society of Engineers, Ostend, Belgium.

16. König, H., and K. O. Stetter. 1982. Isolation and characterization of Methanolobus tindarius, sp. nov., a coccoid methanogen growing only on methanol and methylamines. Zentralbl. Bakteriol. Parasitenkd. Infektionskr. Hyg. Abt. 1 Orig. Reihe C 3:478490.

17. Liu, Y., D. R. Boone, and C. Choy. 1990. Methanohalophilus oregonense sp. nov., a methylotrophic methanogen from an alkaline, saline aquifer. Int. J. Syst. Bacteriol. 40:111-116.

18. Marmur, J. 1961. A procedure for the isolation of deoxyribonucleic acid from microorganisms. J. Mol. Biol. 3:208-218.

19. Mathrani, I. M., D. R. Boone, R. A. Mah, G. E. Fox, and P. P. Lau. 1988. Methanohalophilus zhilinae sp. nov., an alkaliphilic, halophilic, methylotrophic methanogen. Int. J. Syst. Bacteriol. 38:139142.

20. Mesbah, M., U. Premachandran, and W. B. Whitman. 1989. Precise measurement of the guanine-plus-cytosine content of deoxyribonucleic acid by high-performance liquid chromatography. Int. J. Syst. Bacteriol. 39:159-167.

21. Miller, T. L., and M. J. Wolin. 1974. A serum bottle modification of Hungate technique for cultivating obligate anaerobes. Appl. Microbiol. 27:985-987.

22. Ni, S., and D. R. Boone. 1991. Isolation and characterization of a dimethyl sulfide-degrading methanogen, Methanolobus siciliae HI350, from an oil well, characterization of $M$. siciliae $T 4 / M^{T}$, and emendation of $M$. siciliae. Int. J. Syst. Bacteriol. 41:410-416.

23. Ni, S., and D. R. Boone. 1993. Catabolism of dimethylsulfide and methane thiol by methylotrophic methanogens, p. 796-810. In R. S. Oremland (ed.), Biogeochemistry of global change. Chapman \& Hall, Inc., New York.

24. Ni, S., C. R. Woese, H. C. Aldrich, and D. R. Boone. 1994. Transfer of Methanolobus siciliae to the genus Methanosarcina, naming it Methanosarcina siciliae, and emendation of the genus Methanosarcina. Int. J. Syst. Bacteriol. 44:357-359.

25. Oremland, R. S., R. P. Keine, I. M. Mathrani, M. J. Whiticar, and D. R. Boone. 1989. Description of an estuarine methylotrophic methanogen which grows on dimethyl sulfide. Appl. Environ. Microbiol. 55:994-1002.

26. Paterek, J. R., and P. H. Smith. 1988. Methanohalophilus mahii gen. nov., sp. nov., a methylotrophic halophilic methanogen. Int. J. Syst. Bacteriol. 38:122-123.

27. Powell, G. E. 1983. Interpreting gas kinetics of batch culture. Biotechnol. Lett. 5:437-440.

28. Ratkowsky, D. A., R. K. Lowry, T. A. McMeekin, A. N. Stokes, and R. E. Chandler. 1983. Model for bacterial culture growth rate throughout the entire biokinetic temperature range. J. Bacteriol. 154:1222-1226.

29. Schmidt, J. E., A. J. L. Macario, B. K. Ahring, and E. Conway de Macario. 1992. Effect of magnesium on methanogenic subpopulations in a thermophilic acetate-degrading granular consortium. Appl. Environ. Microbiol. 58:862-868.

30. Sowers, K. R., S. F. Baron, and J. G. Ferry. 1984. Methanosarcina acetivorans sp. nov., an acetotrophic methane-producing bacterium isolated from marine sediments. Appl. Environ. Microbiol. 47:971-978.

31. Sowers, K. R., and J. G. Ferry. 1983. Isolation and characterization of a methylotrophic marine methanogen, Methanococcoides methylutens gen. nov., sp. nov. Appl. Environ. Microbiol. 45:684690.

32. Stetter, K. O. 1989. Genus II. Methanolobus König and Stetter 1983, 439, p. 2205-2297. In J. T. Staley, M. P. Bryant, N. Pfennig, 
and J. G. Holt (ed.), Bergey's manual of systematic bacteriology, vol. 3. The Williams \& Wilkins Co., Baltimore.

33. Touzel, J. P., and G. Albagnac. 1983. Isolation and characterization of Methanococcus mazei strain $\mathrm{MC}_{3}$. FEMS Microbiol. Lett. 16:241-245.

34. Whitman, W. B. 1989. Methanococcales, p. 2185-2190. In J. T. Staley, M. P. Bryant, N. Pfennig, and J. G. Holt (ed.), Bergey's manual of systematic bacteriology, vol. 3. The Williams \& Wilkins Co., Baltimore.

35. Zhilina, T. N. 1983. New obligate halophilic methane-producing bacterium. Microbiology (USSR) 52:375-382.

36. Zhilina, T. N., and G. A. Zavarzin. 1987. Methanohalobium evestigatus, n. gen., n. sp. The extremely halophilic methanogenic Archaebacterium. Dokl. Akad. Nauk SSSR 293:464-468. 